Volume 2, Issue 1, April 2021, p. 25-28

P-ISSN 2745-6498, E-ISSN 2745-8008

\title{
Incidence and Characteristic of Psoriasis Patients at Sanjiwani Gianyar Regional Hospital 2018-2019
}

\author{
Annisa Alviariza ${ }^{\left.1^{*}\right)}$; Sayu Widyawati ${ }^{2}$ \\ ${ }^{\left.1^{*}\right), 2}$ Dermato-Venereology Departement, Sanjiwani Gianyar Regional Hospital
}

\begin{abstract}
ARTICLE INFO
Article history:

Received March 09, 2021

Accepted April 16. 2021

Published April 26, 2021

Keyword:
Psoriasis
Characteristic
Incidence
*) corresponding author
Internship Doctor, Dermato-Venereology
Departement, Sanjiwani Gianyar Regional
Hospital, Bali; Jl. Ciung Wanara No.2,
Gianyar, (0361) 943020

Email: annisaalviariza@gmail.com DOI: 10.30604/makein.202126

A B S T R A C T

Psoriasis is a chronic inflammatory skin disease that is characterized by firmly demarcated red plaque covered by a thick squama as a result of impaired proliferation and differentiation of the epidermis. Diagnosis of psoriasis is based on history taking and clinical features. Treatment is determined based on the patient's clinical characteristics and the severity of the disease. This study aims to determine the incidence, characteristics and treatment options of psoriasis patients in the dermatovenereology polyclinic of Sanjiwani Gianyar Regional Hospital in 2018-2019. Retrospective study of psoriasis patients at Sanjiwani Gianyar Regional Hospital in 2018-2019. Data collected from medical records includes sociodemographic data, clinical data and patient treatment history. Within two years, there were 53 new cases of psoriasis. The dominance of psoriasis cases were found in men with a ratio of women and men 1:2,31. From total 53 patients, 37 were male (69,81\%) and 16 female patients (30,19\%). The most common type was psoriasis vulgaris $(73,58 \%)$. The most age group was 31-45 years. The most commonly given regimen of therapy was topical corticosteroids plus oral antihistamines (45,28\%). The most widely given systemic therapy was methotrexate. Accompanying skin infections were found in 6 cases of psoriasis (11,32\%). Based on the results of the study, there were 53 new cases of psoriasis in 2018-2019, psoriasis vulgaris was the most common, the most age group was 31-45 years old, topical corticosteroids plus antihistamines were still the main treatment options for psoriasis patients in Sanjiwani Gianyar Regional Hospital.
\end{abstract}

ABSTRAK: Psoriasis adalah penyakit kulit inflamasi kronis yang ditandai dengan plak merah berbatas tegas tertutup skuama tebal sebagai akibat dari gangguan proliferasi dan diferensiasi epidermis. Diagnosis psoriasis dilakukan berdasarkan anamnesis dan gambaran klinis. Terapi ditentukan berdasarkan karakteristik klinis pasien dan derajat keparahan penyakit. Penelitian retrospektif ini bertujuan untuk mengetahui insiden, karakteristik dan pilihan terapi pasien psoriasis pada Poliklinik Kulit dan Kulit Kelamin RSUD Sanjiwani Gianyar pada tahun 2018-2019. Studi retrospektif selama 2 tahun pada pasien psoriasis di Poliklinik RSUD Sanjiwani Gianyar pada tahun 2018-2019. Data dikumpulkan dari rekam medis mencakup data sosiodemografik, data klinis, serta riwayat pengobatan pasien. Dalam dua tahun terdapat 53 kasus baru psoriasis. Dominasi kasus psoriasis ditemukan pada laki-laki dengan rasio perempuan dan laki-laki 1:2,31. Dari total 53 pasien didapatkan 37 pasien lakilaki $(69,81 \%)$ dan 16 pasien perempuan (30,19\%). Jenis yang paling banyak adalah psoriasis vulgaris (73,58\%). Kelompok usia yang paling banyak adalah 31-45 tahun. Regimen terapi yang paling sering diberikan adalah kortikosteroid topikal ditambah antihistamin oral $(45,28 \%)$. Terapi sistemik yang paling banyak diberikan adalah metotrexate $(43,40 \%)$. Infeksi kulit penyerta terdapat pada 6 kasus psoriasis (11,32\%). Berdasarkan hasil penelitian, didapatkan insiden kasus psoriasis tahun 2018-2019 sebanyak 53 kasus, dengan kasus terbanyak psoriasis vulgaris, kelompok usia terbanyak adalah usia 31-45 tahun, kortikosteroid topikal ditambah antihistamin masih merupakan pilihan terapi utama untuk psoriasis di RSUD Sanjiwani Gianyar. 


\section{INTRODUCTION}

Psoriasis is a chronic inflammatory skin disease characterized by firmly demarcated red plaque covered by a thick squama as a result of impaired proliferation and differentiation of the epidermis. Psoriasis vulgaris is the most common form of psoriasis and affects about $90 \%$ of people with psoriasis. Psoriasis vulgaris is characterized by typical lesions of erythematous plaques and thick scales with a tendency of symmetrical distribution. Sites of predilection include the extensor extremities of elbows and knees, lumbosacral, buttocks and genital area. Scales are thickened constantly covering the erythematous plaques (Gudjonsson JE, Elder JT. Psoriasis. In: Goldsmith LA, Katz SI, Gilchrest BA, Paller AS, Leffell DJ, Wolff K, 2012). The cause of psoriasis is not fully known. Multiple factors such as genetic, immunologic and environmental interactions may trigger the disease (Sugito, TL. 2008)

Psoriasis is found worldwide. It can affects men and women of all ages and ethnicities, in all countries. An estimated $3 \%$ of total population of the world have psoriasis with a sex ratio $1: 1$ between male and female in adults (World Health Organization. 2016). Data from dr. Cipto Mangunkusumo General Hospital in Jakarta shows that there were 338 cases of psoriasis (2.39\%) in 2000 to 2002. While in Sanglah Hospital Denpasar, there were 156 cases (1.4\%) in 2009 (Ariani, C. 2013).

Based on literatures, psoriasis can increase the risk of depression, anxiety and suicidality among patients. In consistent with previous research, psoriasis has moderate to severe negative impacts at patients' quality of life as a result of alteration in their daily activities Psoriasis can also cause a significant morbidity due to the possibility of developing psoriatic arthritis and other systemic diseases (Ariani, C. 2013). Psoriasis Area Severity Index (PASI) is a tool used to measure the severity of psoriasis lessions. PASI measurement was first formulated by Fredricksson and Pettersson. It is now often used in clinical evaluation. Scores of PASI is ranging from $0-72$. PASI calculate range between 0 and 72 with an increase of 0.1 unit, so it is widely used in pharmacy research setting. PASI are subgrouped into mild (PASI $<7$ ), moderate (PASI 7-12) and severe (PASI >12) (Budiastuti, A. 2011)

Our restrospective study aims to evaluate the profiles of psoriasis patients in Dermatovenereology Polyclinic of Sanjiwani General Hospital Gianyar. This retrospective study evaluated patient characteristics, number of cases, types of psoriasis, and therapeutic regimens.

\section{METHOD}

\section{Participant characteristics and research design}

This study used a descriptive research design with a cross sectional approach by looking at medical records to determine the characteristics of psoriasis patients at Sanjiwani Hospital in 2018-2019. Inclusion criterias are patients who have been diagnosed with psoriasis and undergo outpatient treatment at the Dermatovenerology department at Sanjiwani Hospital in 2018-2019 and the patient age above 17 years old. The exclusion criteria is patient who have incomplete medical records.

\section{Sampling procedures}

Samples were obtained from register records and medical records with total sampling taken, where each patient with a diagnosis of psoriasis and meeting the inclusion criteria would be sampled. Data of psoriasis patients in 2018-2019 were collected from medical records include sociodemographic, clinical data and patient's treatment history.

\section{Data analysis}

Data processing and analysis was carried out using computerized techniques with computer devices. Data analysis was performed by means of univariate analysis used to analyze descriptively by calculating the frequency distribution of each research variable.

\section{RESULT AND DISCUSSION}

A retrospective descriptive study of psoriasis was conducted at Dermatovenereology Polyclinic and Medical Records Department of Sanjiwani General Hospital Gianyar in period between January 2018 until December 2019. The data obtained from the medical record were processed and analysed. Data processing and analysis was carried out using computerized techniques with computer devices. Data analysis was performed by means of univariate analysis used to analyze descriptively by calculating the frequency distribution of each research variable by using microsoft excel. There were 53 psoriasis patients in Dermatovenereology Polyclinic Sanjiwani General Hospital between January 2018 and December 2019. The number of patient was increased as many as 3 patients, from 25 patients (47.17\%) in 2018 to 28 patients (52.83\%) in 2019.

There were more male than female patients in our study. Psoriasis cases were predominantly found in men, with female-to-male ratio $1: 2.31$. Thirty seven of 53 (69.81\%) patients were male and 16 (30.19) were female. Patients were subgrouped into five age groups, i.e under 15 years old, $15-30$ years old, $31-45$ years old, $46-60$ years old and over 60 years old. Patients were mostly at the age group of 31-45 years old (41.51\%). According to the disease form, patients were subgrouped into four groups; psoriasis vulgaris, psoriasis gutata, psoriasis pustulata and sebopsoriasis. Most cases, as many as 39 patients (73.58\%), had psoriasis vulgaris. While the least psoriasis type, psoriasis pustulosa, was found on 1 patient (1.87\%). Combination of topical steroid and oral antihistamine was the commonest therapautic regimen used in patients (45.28\%). Meanwhile topical corticosteroid and antifungal only used in 2 patients, specifically in sebopsoriasis type. Methotrexate is one of systemic therapy that most frequently given to patients (43.40\%). Laboratory examinations such as liver function test (serum glutamic oxaloacetic transaminase and serum glutamic-pyruvic transaminase), renal function test (blood urea nitrogen and serum creatinine), and lipid profile was done in patients before giving systemic therapy. Other comorbid skin disease was found in some patients, such as onychomycosis, acneiform eruption and foot ulcer.

\section{DISCUSSION}

Psoriasis was more found in men, as many as 37 patients (69.81\%) with a male-to-female ratio $2.31: 1$. It can be caused because men more often smokes and drinks alcohol as the risk factors.

In our study, patients were mostly at 31-45 years age group. It can be caused of psychological stress that usually happened in that age range. It is consistent with a literature which shows that $68 \%$ of psoriasis patients indicate that 
psychological factors lead to more severe disease (National Psoriasis Foundation, 2012). Other study conducted by Novita Dewi at Sanglah General Hospital in 2012-2014 also

Table 1.

Distribution Characteristics of Psoriasis Patients in Dermatovenereology Polyclinic Sanjiwani Gianyar Regional Hospital

\begin{tabular}{|c|c|c|}
\hline Characteristics & $\mathbf{N}$ & $\%$ \\
\hline \multicolumn{3}{|l|}{ Gender } \\
\hline Man & 37 & 69,81 \\
\hline Woman & 16 & 30,19 \\
\hline \multicolumn{3}{|l|}{ Age } \\
\hline$<15$ & 0 & 0 \\
\hline $15-30$ & 10 & 18,87 \\
\hline $31-45$ & 22 & 41,51 \\
\hline $46-60$ & 18 & 33,96 \\
\hline$>60$ & 3 & 5,72 \\
\hline \multicolumn{3}{|l|}{ Psoriasis Type } \\
\hline Psoriasis vulgaris & 39 & 73,58 \\
\hline Psoriasis gutata & 11 & 20,75 \\
\hline Psoriasis pustulosa & 1 & 1,87 \\
\hline Sebopsoriasis & 2 & 3,8 \\
\hline \multicolumn{3}{|l|}{ Therapy Regimen } \\
\hline \multicolumn{3}{|l|}{ Topical } \\
\hline Emolient & 0 & 0 \\
\hline Corticosteroid & 14 & 26,41 \\
\hline Emolient + Corticosteroid & 0 & 0 \\
\hline \multicolumn{3}{|l|}{ Oral } \\
\hline Oral antihistamine & 7 & 13,21 \\
\hline \multicolumn{3}{|l|}{ Combination } \\
\hline Emolient + Antihistamine & 5 & 9,43 \\
\hline Topical corticosteroid+ Antihistamine & 24 & 45,28 \\
\hline Topical combination + Systemic Corticosteroid & 0 & 0 \\
\hline Topical combination + Antifungal & 2 & 3,78 \\
\hline Topical combination + Antibacterial & 1 & 1,89 \\
\hline \multicolumn{3}{|l|}{ Systemic Therapy } \\
\hline Metotrexate & 23 & 43,40 \\
\hline Siklosporin & 1 & 1,88 \\
\hline Not given & 29 & 54,72 \\
\hline \multicolumn{3}{|l|}{ Other Skin Disease } \\
\hline Present & 6 & 11,32 \\
\hline Not present & 47 & 88,68 \\
\hline
\end{tabular}

Body Surface Area (BSA) is a measurement that describes the percentage of affected body surface area. The importance of determining BSA is to determine the treatment regimen. Based on BSA, the severity of psoriasis vulgaris is subgrouped into mild, moderate, and severe. It is said to be severe if BSA> $30 \%$, moderate if $\mathrm{BSA}>10 \%$, and mild if $\mathrm{BSA}<10 \%$ (Gudjonsson JE, Elder JT. Psoriasis. In: Goldsmith LA, Katz SI, Gilchrest BA, Paller AS, Leffell DJ, Wolff K. 2012).

There are three treatment options for psoriasis includes topical therapy, phototherapy and systemic antimetabolic. Patients with BSA $<10 \%$ is given topical therapy such as topical corticostreroids and D3 analogues. In psoriasis with $\mathrm{BSA}>10 \%$ topical therapy is combined with phototherapy. Narrowband UVB (NB-UVB) and broadband UVB (BB-UVB) is the first choice for phototherapy; while psoralen and UVA (PUVA), excimer laser and climatotherapy is the second line.

In our study, the therapeutic regimen that most commonly given was a combination of topical corticosteroids and oral antihistamines, found in $45.28 \%$ of patients. Topical corticosteroid and antifungal was used in 2 cases, especially in sebopsoriasis patients. While systemic therapy was given to patients with BSA $>30 \%$ and the first line systemic therapy, methotrexate, was the most frequently used. In severe psoriasis with BSA $>30 \%$, patients can be treated by all regimen choices, combined with found that mostly patients were at 31-45 years age group (Dewi, N. and Indira, E. 2018). systemic therapy such as methotrexate, acitretin, alefacept, etanercept, adalimumab, infliximab, and ustekinumab as the first line; and fumaric acid ester (FAE), cyclosporin A, and other agents such as hydroxyurea, 6-thioguanine, cellcept, and sulfasalazine as the second line. Cyclosporine $A$ is not considered as the first line systemic therapy because of its long-term side effects, but it is very useful in short time therapy for the induction of remission (Djuanda A, 2013).

\section{CONCLUSIONS AND RECOMMENDATION}

According to this restrospective study of psoriasis patients in Dermatovenereology Polyclinic Sanjiwani General Hospital in the period of January 2018-December 2019, there were 53 cases of psoriasis came into Dermatovenereology Polyclinic of Sanjiwani General Hospital from January 2018-December 2019. There were 25 cases in 2018 and 28 cases in 2019. Men were more commonly affected than women. The most common form of psoriasis was psoriasis vulgaris. Most patients were in 31-45 years age group. Therapeutic regimen that most frequently used was the combination of topical corticosteroid and antihistamine, while the most systemic therapy used was methotrexate. There were only 6 cases with other skin diseases as comorbid. 


\section{Conflict of Interest Statement}

The authors declared that no potential conflicts of interests with respect to the authorship and publication of this article.

\section{REFERENCES}

Ariani, C. Kadar HDL yang rendah dan kadar trigliserida yang tinggi merupakan faktor risiko psoriasis vulgaris. Thesis Program Pascasarjana Universitas Udayana. 2013. [Online] Tersedia di: http://www.pps.unud.ac.id/pdf_thesis/unud841-998656407 2.tesis\%20cindy\% 20bab\%20i.pdf [Diunduh pada: 17 Desember 2014

Budiastuti, A. (2011). Korelasi Kadar TNF- $\alpha$ dan Skor Psoriasis Area and Severity Index (PASI) pada Pasien Psoriasis. Media Medika Indonesiana, 45 (2): 133-137.

Dewi, N. and Indira, E. (2018). 12. Insiden Dan Profil Psoriasis Di Poliklinik Kulit Dan Kelamin Rumah Sakit Umum Pusat Sanglah Denpasar Periode Januari 2012 Sampai Desember 2014. Jurnal Medika, 7(9)

Djuanda A. Dermatosis Eritroskuamosa (2013). In: Djuanda A, Mochtar H, Siti A, editors. Ilmu Penyakit Kulit dan Kelamin (Edisi ke-6). Jakarta: Fakultas Kedokteran Universitas Indonesia, 2013; p. 189-95.

Gudjonsson JE, Elder JT. (2012). Psoriasis. In: Goldsmith LA, Katz SI, Gilchrest BA, Paller AS, Leffell DJ, Wolff K, editors. Fitzpatrick's Dermatology in general medicine. 8th ed. New York: McGraw Hill; 2012. p. 197-232.

Langey RGB, Krueger GG, Griffiths CEM. (2005). Psoriasis: epidemiology, clinical features, and quality of life. Ann Rheum Dis. 64:ii18-ii23.

Mak RKH, Hundhausen C, Nestle FO. (2012). Progress in Plluska JLB, Rosic VP. epidemiology, natural history, and differential diagnosis. Dove Press Journal. 2012 Psoriasis: understanding immunopathogenesis of psoriasis. Actas Dermosifiliogr. 2019. 100(Suppl 2): 2-13.

Nograles, K., Davidovici, B. and Krueger, J. (2010). New Insights in the Immunologic Basis of Psoriasis. Seminars in Cutaneous Medicine and Surgery, 29(1), pp.3-9.

National Psoriasis Foundation. Psoriasis question and answer. Available from: http://psoriasis.org.

Raychaudhuri, S., Jiang, W., Smoller, B. and Farber, E. (2000). Nerve growth factor and its receptor system in psoriasis. British Journal of Dermatology, 143(1), pp.198200.

Sugito, TL. (2008). Penyakit Papuloeritroskuamosa dan Dermatomikosis Superfisialis pada Bayi dan Anak. Semarang: Badan Penerbit Universitas Diponegoro Semarang.

World Health Organization. (2016). Global report on psoriasis. Switzerland: World Health Organization. 